University of Nebraska - Lincoln

DigitalCommons@University of Nebraska - Lincoln

Nebraska Beef Cattle Reports

Animal Science Department

January 2006

\title{
Effects of Dam Nutrition on Growth and Reproductive Performance of Heifer Calves
}

\author{
Jeremy Martin \\ University of Nebraska-Lincoln \\ Kim Vonnahme \\ North Dakota State University, Fargo, N.D. \\ Greg Lardy \\ North Dakota State University, Fargo, N.D. \\ Don C. Adams \\ University of Nebraska-Lincoln, dadams1@unl.edu \\ Richard N. Funston \\ University of Nebraska-Lincoln, rfunston2@unl.edu
}

Follow this and additional works at: https://digitalcommons.unl.edu/animalscinber

Part of the Animal Sciences Commons

Martin, Jeremy; Vonnahme, Kim; Lardy, Greg; Adams, Don C.; and Funston, Richard N., "Effects of Dam Nutrition on Growth and Reproductive Performance of Heifer Calves" (2006). Nebraska Beef Cattle Reports. 105.

https://digitalcommons.unl.edu/animalscinbcr/105

This Article is brought to you for free and open access by the Animal Science Department at DigitalCommons@University of Nebraska - Lincoln. It has been accepted for inclusion in Nebraska Beef Cattle Reports by an authorized administrator of DigitalCommons@University of Nebraska - Lincoln. 


\section{Effects of Dam Nutrition on Growth and Reproductive Performance of Heifer Calves}

\author{
Jeremy L. Martin \\ Kim A. Vonnahme \\ Greg P. Lardy \\ Don C. Adams \\ Rick N. Funston ${ }^{1}$
}

\section{Summary}

A 3-year experiment evaluated the effects of maternal nutrition on growth and reproductive performance of heifer calves. Supplementing cows with protein during late gestation resulted in heifers that were heavier at weaning and breeding, had higher pregnancy rates, and calved earlier. Allowing cows to graze meadows after calving improved calf weaning weight but not heifer reproductive performance. Heifers from cows that were fed hay after calving had reduced DMI and improved residual feed intake if their dams were supplemented with protein during gestation, but $A D G$ and $G: F$ were not affected by dam supplementation or spring feeding strategies.

\section{Introduction}

The nutritional requirements of spring-calving beef cows grazing dormant Sandhills range during late gestation exceed the nutritional value of the forage. In order to maintain cow body condition, protein supplements are often fed during the last trimester of gestation. These supplements are expensive and do not improve subsequent reproductive performance (2005 Nebraska Beef Report, pp. 7-9). However, the additional cost of protein supplementation is recovered in improved calf performance at weaning and feedlot endpoints (2005 Nebraska Beef Report, pp. 7-9). Additionally, nutrient requirements of the cow are highest during early lactation, which coincides with the beginning of the breeding season. Allowing cows to graze cool-season meadows during this time improves reproductive performance and calf weaning weight compared to cows fed cool-season grass hay (2005 Nebraska Beef Report, pp. 7-9).

The effects of dam nutrition during late gestation and early life on future performance of their heifer calves are not well characterized. Therefore, the objectives of the current study were to determine if supplemental protein during late gestation or postpartum plane of nutrition of cows influences future growth or reproductive performance of their heifer calves.

\section{Procedure}

A 3-year study was conducted with heifers produced at Gudmunsen Sandhills Laboratory (GSL), Whitman, Neb. The heifers were born to cows used in a $2 \times 2$ factorial treatment design to determine effects of late gestation and postpartum nutrition on reproductive performance and calf growth (2005 Nebraska Beef Report, pp 7-9). During the last trimester of gestation (December 1 through February 28) cows received either the equivalent of $1 \mathrm{lb} /$ head/day of a $42 \%$ CP supplement fed three times per week or no protein supplement. The cows were managed as a single group during the calving season, March 1 to April 30. From May 1 until May 31, half the cows were fed cool-season grass hay while the other half grazed sub-irrigated meadow. On June 1 , cows were again combined and were managed in a common group throughout the breeding season and remainder of the production cycle.

During year 1 and year 3 , heifers were managed as a single group from June 1 until the end of data collection. Data available from year 1 is limited to birth and weaning records. In year 2, additional reproduction and calving data was collected. The proportion of heifers cycling before the beginning of the breeding season in year 2 was determined by progesterone concentration in two blood samples collected 10 days apart. Progesterone concentration greater than $1 \mathrm{ng} / \mathrm{mL}$ in either sample was interpreted to indicate ovarian luteal activity. Heifers from year 2 were exposed to bulls for breeding, and first service pregnancy rate was determine using transrectal ultrasonography approximately 30 days after the end of the breeding season.

Heifers born in year 3 remained at GSL for 109 days after weaning and were then transported to the North Dakota State University Animal Nutrition and Physiology Center, Fargo, ND. After an adaptation and training period, heifers from year 3 were individually fed for 84 days using Calan gates. Heifers were housed in a climate-controlled facility with the light cycle being 14 hours light, 10 hours dark. All heifers were allowed ad libitum consumption of hay $(7.5 \%$ CP, $71 \%$ NDF, $52 \%$ ADF) fed in the morning and supplemented daily with $2 \mathrm{lb}$ of $16 \%$ CP pellets in the afternoon. Orts were collected twice weekly and analyzed for DM to determine DMI. Two-day consecutive weights were taken at the beginning and end of the feeding period, with interim weights recorded every $14 \mathrm{~d}$. Following completion of the individual feeding period on May 17, 2005, heifers were transported to the West Central Research and Extension Center, North Platte, Neb. and pre-breeding weights were recorded.

Performance data were analyzed as a 2x2 factorial using PROC MIXED of SAS. Reproductive and calving difficulty data were analyzed using Chi-square procedures in PROC GENMOD of SAS. The model included dam treatment during late gestation and dam treatment during the spring. The interaction between gestation and spring treatments were 
Table 1. Effects of dam protein supplementation during the last trimester of gestation and grazing sub-irrigated meadow during early lactation on growth performance of heifer calves ${ }^{\mathrm{a}}$.

\begin{tabular}{lccccccc}
\hline & \multicolumn{4}{c}{ Treatment $^{\mathrm{b}}$} & & \multicolumn{2}{c}{$P$-values } \\
\cline { 2 - 4 } \cline { 6 - 8 } Item & Prot & NoProt & Meadow & Hay & SEM & Gest & Spring \\
\hline Birth date, Julian day & 86 & 84 & 85 & 86 & 1.4 & 0.29 & 0.67 \\
Birth wt, lb & 79 & 77 & 77 & 79 & 2.2 & 0.25 & 0.15 \\
Act wn wt, lb & 467 & 456 & 468 & 455 & 15 & 0.14 & 0.09 \\
Adj 205 day wt, lb & 498 & 481 & 496 & 483 & 15 & 0.02 & 0.07 \\
Pre-breeding wt, lb & 608 & 586 & 599 & 595 & 20 & 0.04 & 0.70 \\
\hline
\end{tabular}

ancludes birth and weaning (wn) data from 170 heifer calves born from year 1 to year 3 , and prebreeding weights from 91 heifers born in year 2 and year 3 .

${ }^{b}$ No gestation by spring treatment interactions were detected, therefore only main effects are reported. Prot $=$ dams supplemented three times pre week with the equivalent of $1 \mathrm{lb} / \mathrm{hd} / \mathrm{d} 42 \% \mathrm{CP}$ cake during the last trimester of gestation; NoProt = no protein supplement fed to dams during gestation; Meadow = dams grazed sub-irrigated meadows between the end of calving and the breeding season; Hay = dams fed cool-season grass hay from the end of the calving season until initiation of the breeding season.

Table 2. Effects of dam protein supplementation during the last trimester of gestation and grazing sub-irrigated meadow during early lactation on reproductive and calving performance of heifers ${ }^{\mathrm{a}}$.

\begin{tabular}{|c|c|c|c|c|c|c|c|}
\hline \multirow[b]{2}{*}{ Item } & \multicolumn{4}{|c|}{ Treatment $^{\mathrm{b}}$} & \multirow[b]{2}{*}{ SEM } & \multicolumn{2}{|c|}{$P$-values } \\
\hline & Prot & NoProt & Meadow & Hay & & Gest & Spring \\
\hline $\begin{array}{l}\text { Cycling at beginning } \\
\text { of breeding season, } \%\end{array}$ & 47 & 50 & 45 & 53 & & 0.91 & 0.66 \\
\hline $\begin{array}{l}\text { First service pregnancy } \\
\text { rate, } \%\end{array}$ & 88 & 45 & 64 & 65 & & 0.003 & 0.59 \\
\hline Overall pregnancy rate, $\%$ & 94 & 73 & 82 & 82 & & 0.06 & 0.76 \\
\hline Calving date, Julian day & 63 & 71 & 68 & 66 & 3.3 & 0.07 & 0.71 \\
\hline Calf birth wt, lb & 75 & 74 & 73 & 76 & 2.2 & 0.61 & 0.29 \\
\hline Unassisted births, \% & 69 & 38 & 56 & 50 & & 0.08 & 0.92 \\
\hline
\end{tabular}

${ }^{a}$ Includes reproductive data from 39 heifers born in year 2 and calving data from 32 heifers that became pregnant.

${ }^{b}$ No gestation by spring treatment interactions were detected, therefore only main effects are reported. Prot $=$ dams supplemented three times pre week with the equivalent of $1 \mathrm{lb} / \mathrm{hd} /$ day $42 \% \mathrm{CP}$ cake during the last trimester of gestation; NoProt $=$ no protein supplement fed to dams during gestation; Meadow $=$ dams grazed sub-irrigated meadows between the end of calving and the breeding season; Hay = dams fed cool-season grass hay from the end of the calving season until initiation of the breeding season.

Table 3. Effects of dam protein supplementation during the last trimester of gestation and grazing sub-irrigated meadow during early lactation on growth, BCS, and residual feed intake of heifers individually-fed for 84 days. ${ }^{a}$

\begin{tabular}{|c|c|c|c|c|c|c|c|c|}
\hline \multirow[b]{2}{*}{ Item } & \multicolumn{4}{|c|}{ Treatment Effects ${ }^{b}$} & \multirow[b]{2}{*}{ SEM } & \multirow[b]{2}{*}{ G } & \multicolumn{2}{|c|}{$P$-values } \\
\hline & $\mathrm{P} / \mathrm{M}$ & $\mathrm{P} / \mathrm{H}$ & $\mathrm{NP} / \mathrm{M}$ & $\mathrm{NP} / \mathrm{H}$ & & & $\mathrm{Sp}$ & $\mathrm{G}^{*} \mathrm{Sp}$ \\
\hline Initial wt, lb & 607 & 574 & 564 & 571 & 19 & 0.19 & 0.45 & 0.26 \\
\hline Initial BCS & 5.53 & 5.54 & 5.43 & 5.54 & 0.10 & 0.62 & 0.53 & 0.65 \\
\hline Final wt, lb & 684 & 656 & 646 & 631 & 18 & 0.08 & 0.22 & 0.71 \\
\hline Final BCS & 5.13 & 4.96 & 4.96 & 4.92 & 0.09 & 0.20 & 0.23 & 0.42 \\
\hline ADG, lb/day & 0.81 & 0.93 & 0.92 & 0.85 & 0.14 & 0.86 & 0.75 & 0.15 \\
\hline $\mathrm{DMI}, \mathrm{lb} /$ day & $14.49^{\mathrm{de}}$ & $15.25^{\mathrm{d}}$ & $14.98^{\mathrm{de}}$ & $13.67^{\mathrm{e}}$ & 0.63 & 0.37 & 0.65 & 0.09 \\
\hline $\mathrm{G}: \mathrm{F}$ & 0.057 & 0.062 & 0.060 & 0.067 & 0.007 & 0.40 & 0.27 & 0.88 \\
\hline $\mathrm{RFI}, \mathrm{lb} / \mathrm{day}^{\mathrm{c}}$ & $-0.30^{\text {de }}$ & $0.61^{\mathrm{d}}$ & $0.40^{\mathrm{de}}$ & $-0.90^{\mathrm{e}}$ & 0.62 & 0.50 & 0.74 & 0.07 \\
\hline
\end{tabular}

ancludes data from 50 heifers born in year 3 .

${ }^{\mathrm{b}} \mathrm{P} / \mathrm{M}=$ dams supplemented with the equivalent of $1 \mathrm{lb} / \mathrm{hd} / \mathrm{d}$ of $42 \% \mathrm{CP}$ cake during gestation and grazed meadows from the end of the calving season until the breeding season; $\mathrm{P} / \mathrm{H}=$ dams supplemented with the equivalent of $1 \mathrm{lb} / \mathrm{hd} / \mathrm{d}$ of $42 \% \mathrm{CP}$ cake during gestation and were fed cool-season grass hay from the end of the calving season until the breeding season; NP/M = dams not supplemented with protein during gestation, grazed meadows between in the interval between the end of calving and initiation of the breeding season; $\mathrm{NP} / \mathrm{H}=$ dams not supplemented with protein during gestation, fed cool-season grass hay between in the interval between the end of calving and initiation of the breeding season.

${ }^{c}$ Residual feed intake, the difference between observed DMI and predicted DMI.

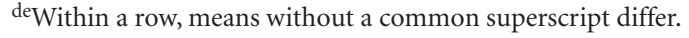

included for data sets when significant. In multiyear analyses, year was included as a random variable. Pen was included in the random statement for heifers in the individual feeding trial.

For year 3, residual feed intake (RFI) was calculated by regressing DMI on mid-test weight and ADG using PROC REG of SAS. The slope coefficients $\left(b_{m}\right.$ and $b_{g}$, respectively) from these analyses were then used to predict DMI using the following equation: Predicted DMI = Average DMI of the group $+b_{m}$ (mid-test weight $)+b_{g}(A D G)$. Residual feed intake was calculated as the difference between observed and predicted DMI; therefore, lower values indicate increased efficiency.

\section{Results}

Birth and weaning data are summarized in Table 1. Dam nutrition did not affect $(P>0.10)$ heifer birth date or birth weight. Supplementing cows with protein during late gestation tended $(P=0.14)$ to increase subsequent heifer weaning weight, and increased $(P=0.02)$ adjusted 205 day weight. Cows that grazed sub-irrigated meadows during the spring produced heifer calves with increased actual $(P=0.09)$ and adjusted $(P=0.07)$ weaning weight compared to heifers from cows fed hay. Pre-breeding weight was greater $(P=0.04)$ for heifers from proteinsupplemented dams than heifers from unsupplemented dams, but spring treatment did not affect $(P>0.10)$ heifer pre- breeding weight. Overall ADG between weaning and the first breeding season was not affected by dam treatment $(P>0.10$; data not shown).

There was no effect $(P>0.10)$ of dam nutrition on the proportion of heifers from year 2 exhibiting ovarian luteal activity prior to the breeding season (Table 2). Furthermore, there was no difference $(P>0.10)$ for pregnancy rates or calving data between heifers whose dams grazed subirrigated meadows and heifers whose

(Continued on next page) 
dams were fed hay in the spring. However, first service pregnancy rate was $88 \%$ for heifers from proteinsupplemented dams and $45 \%$ for heifers born to unsupplemented cows $(P=0.003)$. Overall pregnancy rate was $94 \%$ versus $73 \%(P=0.06)$ for heifers from protein-supplemented or unsupplemented dams, respectively. Heifers born to cows supplemented with protein during late gestation calved earlier $(P=0.07$; Table 2$)$ and had a greater proportion of unassisted births ( $69 \%$ vs $38 \%$; $P=0.08)$ than heifers whose dams were not supplemented with protein during late gestation. However, no differences $(P$ $=0.61)$ in birth weight were detected. Weight and BCS prior to the second breeding season were not affected by maternal nutrition $(P>0.10$; data not shown).

Data from the individual feeding trial (yr 3) are presented as simple effects (Table 3). Heifers from protein-supplemented cows were heavier $(P=0.08)$ at the end of the 84-day trial but had similar initial weights $(P>0.10)$, and similar BCS at both time points $(P>0.10)$ compared to heifers from cows that were not supplemented during gestation. Dam nutrition after calving did not affect weight nor BCS $(P>0.10)$. Neither ADG nor the ratio of gain to feed was affected $(P>0.10)$ by maternal nutrition.
Dry matter intake and RFI were affected $(P=0.09, P=0.07$, respectively) by the interaction of maternal nutrition during late gestation and after the calving season. Heifers born to protein supplemented dams had greater DMI $(P=0.09)$ if their dams were fed hay in the spring, but not if their dams grazed meadows after calving $(P>0.10)$. Similarly, heifers from protein supplemented dams had higher RFI $(P=0.07)$ if their dams were fed hay in the spring, but not if their dams grazed meadows during the postpartum period $(P>0.10)$. Higher RFI values indicate that heifers from protein supplemented cows fed hay were less feed efficient than heifers from unsupplemented cows fed hay after calving. In this data set, it appears that selecting for feed efficiency based on RFI would result in reduced DMI, but not improved ADG. In fact, the heifers with more favorable RFI also had numerically lower ADG, but the differences were not statistically significant. Gain to feed ratio was not affected by treatment.

\section{Conclusion}

Supplementing cows with protein during late gestation not only affects the nutritional plane of the cow, but has lasting effects on their heifer calf weight and reproductive performance.
Heifers from protein-supplemented cows were heavier at weaning and maintained this advantage through the beginning of the breeding season, but postweaning rate of gain was similar. These same heifers tended to have higher pregnancy rates, calved earlier, and had a higher proportion of unassisted births. Cows grazing subirrigated meadows also weaned heavier calves but this weight advantage was not maintained, and reproductive performance of the heifers was not improved. In young cattle, RFI is a measure of feed efficiency correlated to reduced mature cow feed intake but not mature cow size (Arthur et al, 2004 J. Anim. Sci. Suppl. 1:449). Heifers from cows receiving protein supplement during gestation that were fed hay after calving had more favorable RFI and reduced DMI, although G:F was not influenced by maternal nutrition.

\footnotetext{
${ }^{1}$ Jeremy Martin, graduate student; Kim Vonnahme, assistant professor, Animal Science, North Dakota State University, Fargo, N.D.; Greg Lardy, professor, Animal Science, North Dakota State University, Fargo, N.D.; Don Adams, professor, Animal Science, West Central Research and Extension Center, North Platte; Rick Funston, assistant professor, Animal Science, West Central Research and Extension Center, North Platte.
} 